\title{
Lack of Interference in Long-Term Memory for Socially Learned Food Preferences in Rats (Rattus norvegicus)
}

\author{
Bennett G. Galef Jr., Wing Yee Lee, and Elaine E. Whiskin \\ McMaster University
}

\begin{abstract}
Outside the laboratory, rats (Rattus norvegicus) are likely both to interact with several conspecifics that have eaten various foods and to eat a variety of foods themselves before they encounter any particular food for which they have a socially enhanced preference. Here the authors examine the stability of rats' socially learned food preferences following 6 days of potentially disruptive ingestive experiences. The authors found that 6 days of (a) eating unfamiliar foods, (b) interacting with demonstrators that had eaten unfamiliar foods, or (c) both eating unfamiliar foods and interacting with demonstrators that had eaten those foods had no measurable effect on rats' socially learned food preferences. The stability of socially enhanced food preferences over time and despite potentially disruptive experiences is consistent with the view that social learning about foods is an important determinant of the food choices of free-living Norway rats.
\end{abstract}

After a Norway rat (an observer) interacts briefly with a conspecific that has recently eaten a distinctively flavored food (a demonstrator), the observer shows a substantial enhancement of its preference for whatever food its demonstrator ate (Galef \& Wigmore, 1983). Experience of diet-identifying cues that either come from particles of recently eaten food clinging to the fur of a rat or escape from a rat's digestive track for some hours after it has eaten (Galef \& Kennett, 1985; Galef \& Stein, 1985), together with sulfur compounds that are a normal part of rat breath, enhances an observer rat's preference for whatever food its demonstrator ate (Galef, Mason, Preti, \& Bean, 1988).

Socially induced enhanced flavor preferences, resulting from experience of the odor of foods on the breath of a conspecific, are quite powerful. They can reverse both flavor aversions acquired as a result of eating an unfamiliar food before becoming ill (Galef, 1985, 1986; Galef \& Whiskin, 1998) and species-typical aversions to piquant foods (Galef, 1989). Socially induced changes in flavor preferences of rats are also surprisingly durable. Even 30 days after observers and demonstrators interact, the enhanced preferences of observers for the foods that their respective demonstrators ate are as strong as they were on the day that social learning occurred (Galef, 1989; Galef \& Whiskin, 2003).

In all previous studies of the stability of socially induced enhancement of food preference, during the days or weeks intervening between social learning of flavor preferences and testing of observers, observers were maintained in social isolation and ate a

Bennett G. Galef Jr., Wing Yee Lee, and Elaine E. Whiskin, Department of Psychology, McMaster University, Hamilton, Ontario, Canada.

Wing Yee Lee is now at the Ontario Institute for Studies in Education, University of Toronto, Toronto, Ontario, Canada.

This research was supported by grants from the Natural Sciences and Engineering Research Council of Canada.

Correspondence concerning this article should be addressed to Bennett G. Galef Jr., Department of Psychology, McMaster University, Hamilton, Ontario L8S 4K1, Canada. E-mail: galef@mcmaster.ca single, familiar, unflavored diet (e.g., Galef, 1989; Galef \& Whiskin, 2003; Winocur, 1990). Free-living Norway rats live as members of colonies that inhabit burrow systems that individuals leave to forage and to which they return between foraging bouts (Calhoun, 1962; Telle, 1966). Further, free-living rats are dietary generalists (Clark, 1982; Taylor, 1978). Consequently, each colony member is likely both to eat several different foods and to encounter individuals that have eaten several different foods in the interval between acquiring information about a food socially and discovering that food while foraging. It follows that for socially acquired food preferences to affect the food choices of free-living rats, such preferences would have to be stable in the face of potentially disruptive social and ingestive experiences occurring during the interval between acquisition of a socially enhanced preference and encounter with the food for which a preference had been socially induced.

Here we show that socially induced enhanced preferences for distinctively flavored foods are sustained for several days even if, during that time, an observer rat both eats unfamiliar foods and interacts with demonstrator rats that have eaten unfamiliar foods other than those for which the observer has acquired an enhanced preference socially.

\section{Experiment 1}

We conducted Experiment 1 as three independent studies of similar design that varied only in the experiences that we provided observer rats during a 6-day interval between when each observer interacted with a demonstrator fed a distinctively flavored food and testing of the observer's food preferences. The cost of maintaining large numbers of subjects for extended periods led to our choosing a 6-day interval between social induction of a preference and testing, though there is every reason to believe the same outcome would have been obtained with intervals of a month or more between social experience and testing (Galef \& Whiskin, 2003). 


\section{Method}

\section{Subjects}

Sixty-eight 7-week-old, female Long-Evans rats (Rattus norvegicus), obtained from Charles River Canada (St. Constant, Quebec, Canada), served as observers. After transport to our laboratory (Hamilton, Ontario, Canada) and before the start of the experiment, subjects were maintained for 1 to 2 weeks with ad libitum access to pellets of Rodent Diet 8640 (Harlan Teklad, Madison, Wisconsin) and tap water. An additional sixtyeight 9-week-old, female Long-Evans rats that had served as observers in other experiments served as demonstrators. We randomly assigned half of the observers and demonstrators in each study to control and experimental groups whose treatment is described in the Procedure section.

\section{Apparatus}

During the experiment, each demonstrator and each observer resided in an individual, wire-mesh hanging cage, measuring $21.5 \mathrm{~cm}$ high $\times 24.0 \mathrm{~cm}$ wide $\times 27.5 \mathrm{~cm}$ deep, and were provided ad libitum access to tap water. We housed racks of cages in a temperature- and humidity-controlled colony room illuminated on a 12:12-hr light-dark cycle. All subjects ate powdered foods from semicircular stainless steel cups $8 \mathrm{~cm}$ in diameter and $4 \mathrm{~cm}$ deep. To prevent spillage, we filled these cups to a depth of $2 \mathrm{~cm}$ or less, and we monitored spillage, which rarely occurred, by examining the tray under each subject's food cups.

\section{Diets}

We composed five distinctively flavored foods by adding either $2.0 \mathrm{~g}$ of Hershey's Pure Cocoa (diet coc), $1.0 \mathrm{~g}$ of ground cinnamon (diet cin), $1.0 \mathrm{~g}$ of ground anise (diet ani), $2.0 \mathrm{~g}$ of ground marjoram (diet mar), or $0.5 \mathrm{~g}$ of ground thyme (diet thy) to $100 \mathrm{~g}$ of powdered Rodent Diet 8640 (diet 8640). All herbs and spices were purchased in bulk from the Horn of Plenty (Dundas, Ontario, Canada).

\section{Procedure}

Study 1: Effects of eating other foods. To begin Study 1, we placed 12 demonstrators on a $23-\mathrm{hr}$ schedule of food deprivation. For the first 2 days of scheduled feeding, we fed each demonstrator diet $8640 \mathrm{for} 1 \mathrm{hr} /$ day. On the third day of scheduled feeding, 6 demonstrators ate for $1 \mathrm{hr}$ from a weighed food cup containing diet cin, and 6 ate from a weighed food cup containing diet coc. At the end of the 1-hr feeding period, we reweighed demonstrators' food cups to be sure each demonstrator had eaten at least $5 \mathrm{~g}$ and then moved each demonstrator to the home cage of an observer, where it remained for $30 \mathrm{~min}$. When the 30 -min period of interaction between demonstrator and observer had ended, we removed demonstrators both from their observers' cages and from the experiment.

Immediately after we removed demonstrators from their observers' home cages, we offered each observer ad libitum access to either diet ani or diet mar for $24 \mathrm{hr}$. Each day for the next 5 days, we provided each observer with ad libitum access to diets ani and mar in alternation. After 6 days of feeding on diets ani and mar, we offered each observer a choice between diets cin and coc for $24 \mathrm{hr}$.

We treated the 12 observers and 12 demonstrators randomly assigned to the control group exactly as we treated those assigned to the experimental group described above, with one exception: For the 6 days that we fed observers assigned to the experimental group diets ani and mar, we fed observers assigned to the control group their unflavored, familiar maintenance diet, diet 8640 .

Study 2: Effects of interacting with demonstrators fed other foods. The procedure of Study 2 was similar to that of Study 1. As in Study 1, we started by allowing each observer to interact for $30 \mathrm{~min}$ with a demonstrator that had just eaten either diet cin or diet coc for $1 \mathrm{hr}$. However, in the present study, we continued to maintain demonstrators on a 23 -hr schedule of food deprivation for the next 6 days, and instead of giving observers diets ani and mar to eat each day for 6 days, we gave observers ad libitum access to the familiar diet 8640 for 6 days.

We allowed each observer to interact for $30 \mathrm{~min}$ on each of the 6 days of the experiment with demonstrators that we had alternately fed diet ani or diet mar for $1 \mathrm{hr}$ before we placed it with its observer. Finally, as in Study 1 , we offered each observer a choice between weighed samples of diets cin and coc for $24 \mathrm{hr}$ starting immediately after each observer interacted with a demonstrator for the last time.

We treated the 12 demonstrators and 12 observers that we had randomly assigned to the control group exactly as we treated subjects assigned to the control group in Study 1. For the 6 days that experimental subjects interacted with demonstrators fed diets ani and mar, control subjects remained in social isolation eating diet 8640 ad libitum.

Study 3: Effects both of interacting with a demonstrator eating other foods and of eating those foods. The procedure of Study 3 was identical to that of Study 2, with two exceptions: First, each demonstrator alternately ate one of three diets (diets ani, mar, and thy) immediately before it interacted with its observer. Second, for $24 \mathrm{hr}$ after interacting with a demonstrator fed diet ani, mar, or thy, each observer had ad libitum access to the diet that its demonstrator had eaten. As in Studies 1 and 2, after 6 days of treatment, we provided each observer assigned to the experimental condition with a choice for $24 \mathrm{hr}$ between weighed samples of diets cin and coc after it had 24-hr access to whichever diet the last of its demonstrators ate. We treated the 10 demonstrators and 10 observers randomly assigned to the control group in Study 3 exactly as we treated those assigned to the control groups in Studies 1 and 2.

\section{Data Analysis}

To compare diet preferences of observers assigned to experimental and control conditions in each study, we first calculated the percentage of each observer's 24-hr intake that was the diet that its demonstrator had eaten (i.e., the percentage of diet cin eaten by observers whose demonstrators had eaten diet cin and the percentage of diet coc eaten by observers whose demonstrators had eaten diet coc). We then calculated the mean and standard error of the mean of each group's percentage of demonstrators' diets eaten and used Student's $t$ tests to determine whether there were reliable differences between the preferences of subjects assigned to control and experimental conditions in each study. To determine whether the percentage of demonstrators' diets eaten by observers within a condition within a study differed from chance, we used one-sample $t$ tests.

\section{Results and Discussion}

In each of the three studies in Experiment 1, observers assigned to both experimental and control conditions showed a significant effect of interacting with demonstrators fed either diet cin or diet $\operatorname{coc}$ on their relative intake of the two diets during testing 6 days later; one-sample $t$ tests: Study 1, for both conditions, $t(11)>$ 13.22, $p<.0001$; Study 2 , for both conditions, $t(11)>8.68, p<$ .0001 ; and Study 3 , for both conditions, $t(9)>11.50, p<.0001$ (see Figure 1). Comparisons (Student's $t$ tests) of preferences for demonstrators' diets revealed no differences between observers assigned to experimental and control conditions in any of the three studies: Studies 1 and 2, for both conditions, $t(22)<0.55$, $n s$ Study $3, t(18)=0.65, n s$ (Figure 1). The results demonstrate (a) highly reliable effects of demonstrators on observers' diet preferences that lasted at least 6 days and (b) no effect of eating unfamiliar foods (Study 1), interacting with demonstrators that had eaten unfamiliar foods (Study 2), or both interacting with demonstrators that had eaten unfamiliar foods and eating those foods 


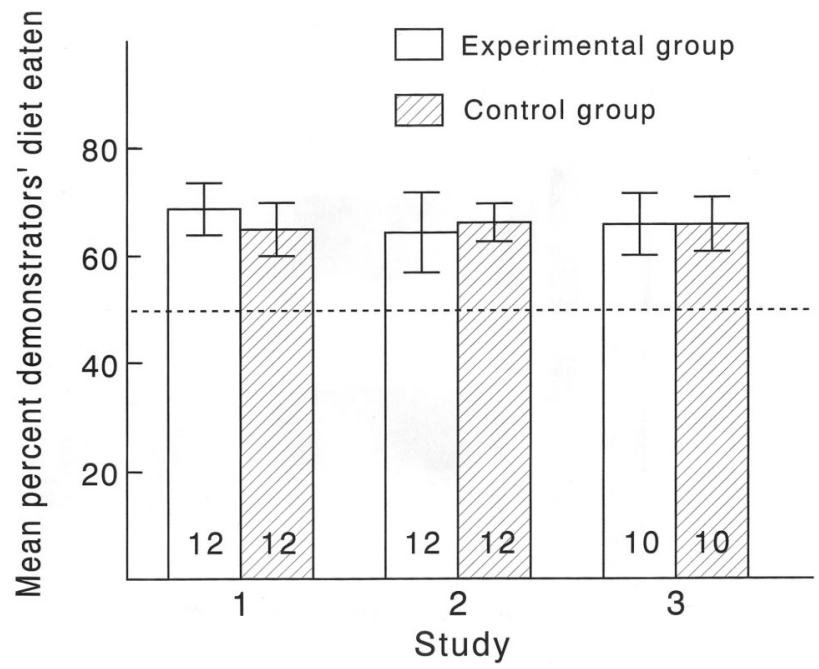

Figure 1. Mean percentage of demonstrators' diets eaten by observers assigned to experimental and control conditions in Studies 1, 2, and 3 of Experiment 1. Error bars represent standard errors of the mean.

(Study 3) on observers' retention of socially learned food preferences. In sum, observer rats retained for at least 6 days the information that they had acquired from demonstrators even after several potentially interfering events occurred during the interval between information acquisition and information use.

Although the results of Experiment 1 suggest that memory of socially acquired information about foods is relatively impervious to relevant interfering events, two obvious potential confounds need to be excluded before that conclusion is accepted. First, it is possible that diets cin and coc are particularly salient stimuli and, consequently, that the results of Experiment 1 reflect the salience of diets cin and coc rather than a more general resistance to interference of the memory of socially acquired information about foods. Second, in all three studies in Experiment 1, subjects assigned to experimental conditions learned socially about diets cin and coc before they experienced potentially interfering stimuli. It is possible that the observed resistance to interference of socially learned food preferences found in Experiment 1 reflected particularly strong primacy effects in social induction of food preferences. These two possibilities are examined in Experiments 2 and 3 , respectively.

\section{Experiment 2}

We examined the possibility that diets cin and coc are particularly salient stimuli for social enhancement of flavor preferences.

\section{Method}

\section{Subjects}

Twenty-eight 7-week-old, female Long-Evans rats obtained from Charles River Canada served as observers. An additional twenty-eight 9-week-old, female Long-Evans rats that had previously served as observers in Experiment 1 served as demonstrators.

\section{Apparatus and Diets}

We used the same apparatus that we used throughout Experiment 1 and the same diets as in Study 3 of Experiment 1.

\section{Procedure}

The procedure of Experiment 2 was similar to that of Study 3 of Experiment 1 with three exceptions: First, the 15 observers assigned to the experimental condition learned socially about diets ani and mar rather than about diets cin and coc. Second, observers assigned to the experimental condition interacted with demonstrators fed diets cin, coc, and thy and ingested those diets for 6 days before testing. Consequently, observers assigned to the experimental condition first interacted with demonstrators fed either diet mar or diet ani, then interacted daily for 6 days with demonstrators fed either diet cin, diet coc, or diet thy and ate those diets, and finally were tested for $24 \mathrm{hr}$ for their preference between diets ani and mar.

We treated the 13 observers and 13 demonstrators randomly assigned to the control condition exactly as we treated those assigned to the experimental condition with one exception: For the 6 days that observers assigned to the experimental condition both interacted with demonstrators fed diets cin, coc, and thy and ate those diets, we fed observers assigned to the control condition their unflavored, familiar maintenance diet, diet 8640 .

\section{Results and Discussion}

Subjects assigned to both experimental and control conditions showed reliable preferences for their respective demonstrators' diets: one-sample $t$ tests revealed that for the experimental group, $t(14)=11.66, p<.0001$; and for the control group, $t(12)=10.31$, $p<.0001$ (see Figure 2). Observers assigned to control and experimental conditions did not differ in their preferences for demonstrators' diets: Student's $t$ test, $t(26)=0.16, n s$. Clearly the outcome of Experiment 1 was not a consequence of unanticipated salience of test diets cin and coc.

\section{Experiment 3}

We undertook Experiment 3 to determine whether socially acquired food preferences are particularly sensitive to primacy effects.

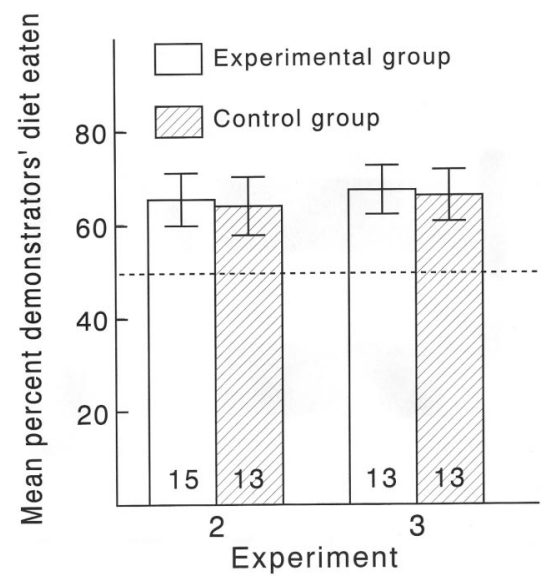

Figure 2. Mean percentage of demonstrators' diets eaten by observers assigned to experimental and control conditions in Experiments 2 and 3. Error bars represent standard errors of the mean. 


\section{Method}

\section{Subjects}

Twenty-six 7-week-old, female Long-Evans rats obtained from Charles River Canada served as observers. An additional twenty-six 9-week-old, female Long-Evans rats that had served as observers in Experiment 2 served as demonstrators.

\section{Apparatus and Diets}

We used the same apparatus that we used in Experiments 1 and 2 and the same diets (cin, coc, ani, mar, and thy) that we used in both Study 3 of Experiment 1 and Experiment 2.

\section{Procedure}

The procedure was similar to that of Study 3 of Experiment 1. However, here, for $24 \mathrm{hr}$ before the 13 observers assigned to the experimental condition interacted with a demonstrator fed either diet cin or diet coc, they interacted with a demonstrator fed diet ani, diet mar, or diet thy and, for the next $24 \mathrm{hr}$, had ad libitum access to whichever diet their respective demonstrators had eaten. Observers then interacted for 30 min with a demonstrator fed either diet cin or diet coc. Twenty-four hours later and each day for the next 6 days, each observer interacted for $30 \mathrm{~min}$ with a demonstrator that had eaten, in random order, diet ani, diet mar, or diet thy. For the $24 \mathrm{hr}$ after interacting with a demonstrator, each observer had ad libitum access to whichever diet its demonstrator had eaten. Finally, each observer was offered a choice between diet cin and diet coc for $24 \mathrm{hr}$.

The 13 observers that we had randomly assigned to the control condition, like observers assigned to the control conditions of Experiment 1 and 2 , interacted with demonstrators fed either diet cin or diet coc and then ate diet 8640 for 6 days before choosing between diets cin and coc.

\section{Results and Discussion}

Observers assigned to both experimental and control conditions showed a reliable preference for their respective demonstrators' diets: one-sample $t$ tests revealed that for the experimental group, $t(12)=12.02, p<.0001$; and for the control group, $t(12)=12.94$, $p<.0001$ (Figure 2). Observers assigned to control and experimental conditions did not differ in their preferences for their respective demonstrators' diets: Student's $t$ test, $t(24)=0.16, n s$.

The finding in the present experiment that observers maintained an enhanced preference for diet cin or diet coc, even when those were not the diets fed to the first demonstrators with whom observers interacted, indicates that the outcome of Experiment 1 was not a consequence of our introducing observers to demonstrators fed diet cin or diet coc before they interacted with demonstrators fed other diets.

\section{General Discussion}

Taken together, the results of the present experiments indicate that socially induced enhanced preferences for distinctively flavored foods are not disrupted by information about other foods acquired during the interval between learning socially about a food and encountering that food. This finding increases the probability that socially learned food preferences shape the food choices of free-living Norway rats living, as most wild Norway rats do, as members of colonies that subsist on a variety of foods (Clark, 1982; Steiniger, 1950; Taylor, 1978; Telle, 1966).
Norway rats are not the only animals that have been shown to exhibit an enhanced preference for a food after interacting with a recently fed conspecific demonstrator at a location distant from the site where the demonstrator fed. Such social enhancement of food preference has been found in a number of New World and Old World rodent species, including Belding's ground squirrel (Spermophilus beldingi; Peacock \& Jenkins, 1988), house mice (Mus domesticus; Choleris, Cong, Liu, Mainardi, \& Valsecchi, 1997; Valsecchi \& Galef, 1989), spiny mice (Acomys carihinus; McFayden-Ketchum \& Porter, 1989), Mongolian gerbils (Meriones unguiculatus; Galef et al., 1998; Valsecchi, Choleris, Moles, Guo, \& Mainardi, 1996), naked mole rats (Heterocephalus glaber; Faulkes, 1999), roof rats (Rattus rattus; Chou, Marsh, \& Richerson, 2000), pine voles (Microtus pinetorum; Solomon, Yaeger, \& Beeler, 2002), and golden hamsters (Mesocricetus auratus) and dwarf hamsters (Phodopus campbelli; Lupfer, Frieman, \& Coonfield, 2003). Although analyses of social enhancement of food preference in other rodent species have not been carried as far as they have been in Norway rats (e.g., Galef et al., 1988; Galef \& Stein, 1985), all are social animals with varied diets, and all should face problems similar to those faced by Norway rats when foraging. Demonstration of longevity and stability of Norway rats' socially enhanced preferences for foods thus suggests that social learning about foods may play a meaningful role in food selection by free-living members of all species in which social interaction at a distance from a feeding site can affect subsequent food choices.

\section{References}

Calhoun, J. B. (1962). The ecology and sociology of the Norway rat Bethesda, MD: U.S. Department of Health, Education, and Welfare.

Choleris, E., Cong, G., Liu, H., Mainardi, M., \& Valsecchi, P. (1997). The effect of demonstrator age and number on duration of socially-induced food preferences in house mouse (Mus domesticus). Behavioural Processes, 41, 69-77.

Chou, L.-S., Marsh, R. E., \& Richerson, P. J. (2000). Constraints on social transmission of food selection by roof rats, Rattus rattus. Acta Zoologica Taiwanica, 11, 95-109.

Clark, D. A. (1982). Foraging behavior of a vertebrate omnivore (Rattus rattus): Meal structure, sampling, and diet breadth. Ecology, 63, 763772

Faulkes, C. G. (1999). Social transmission of information in a eusocial rodent, the naked mole-rat (Heterocephalus glaber). In H. O. Box \& K. R. Gibson (Eds.), Mammalian social learning: Comparative and ecological perspectives (pp. 205-220). Cambridge, England: Cambridge University Press.

Galef, B. G., Jr. (1985). Socially induced diet preferences can partially reverse LiCl-induced diet aversion. Animal Learning \& Behavior, 13 415-418.

Galef, B. G., Jr. (1986). Social interaction modifies learned aversions, sodium appetite, and both palatability and handling-time induced dietary preference in rats (Rattus norvegicus). Journal of Comparative Psychology, 100, 432-439.

Galef, B. G., Jr. (1989). Enduring social enhancement of rats' preferences for the palatable and the piquant. Appetite, 13, 81-92.

Galef, B. G., Jr., \& Kennett, D. J. (1985). Delays after eating: Effects on transmission of diet preferences and aversions. Animal Learning \& Behavior, 13, 39-43.

Galef, B. G., Jr., Mason, J. R., Preti, G., \& Bean, N. J. (1988). Carbon disulfide: A semiochemical mediating socially-induced diet choice in rats. Physiology \& Behavior, 42, 119-124.

Galef, B. G., Jr., Rudolf, B., Whiskin, E. E., Choleris, E., Mainardi, M., \& 
Valsecchi, P. (1998). Familiarity and relatedness: Effects on social learning about foods by Norway rats and Mongolian gerbils. Animal Learning \& Behavior, 26, 448-454.

Galef, B. G., Jr., \& Stein, M. (1985). Demonstrator influence on observer diet preference: Analyses of critical social interactions and olfactory signals. Animal Learning \& Behavior, 13, 31-38.

Galef, B. G., Jr., \& Whiskin, E. E. (1998). Limits on social influences on food choices of Norway rats. Animal Behaviour, 56, 1015-1020.

Galef, B. G., Jr., \& Whiskin, E. E. (2003). Socially transmitted food preferences can be used to study long-term memory in rats. Learning \& Behavior, 31, 160-164.

Galef, B. G., Jr., \& Wigmore, S. W. (1983). Transfer of information concerning distant foods: A laboratory investigation of the "informationcentre" hypothesis. Animal Behaviour, 31, 748-758.

Lupfer, G., Frieman, J., \& Coonfield, D. (2003). Social transmission of flavor preferences in two species of hamsters (Mesocricetus auratus and Phodopus campbelli). Journal of Comparative Psychology, 117, 449455 .

McFadyen-Ketchum, S. A., \& Porter, R. H. (1989). Transmission of food preferences in spiny mice (Acomys cahirinus) via nose-mouth interaction. Behavioral Ecology and Sociobiology, 24, 59-62.

Peacock, M. M., \& Jenkins, S. H. (1988). Development of food preferences: Social learning by Belding's ground squirrels, Spermophilus beldingi. Behavioral Ecology and Sociobiology, 22, 393-399.

Solomon, N. G., Yaeger, C. S., \& Beeler, L. A. (2002). Social transmission and memory of food preferences in pine voles (Microtus pinetorum). Journal of Comparative Psychology, 116, 35-38.
Steiniger, von F. (1950). Beitrage zur Sociologie und sonstigen Biologie der Wanderatte [Contribution to the sociology and other biology of the brown rat]. Zeitschrift fur Tierpsychologie, 7, 356-379.

Taylor, K. D. (1978). Range of movement and activity of common rats (Rattus norvegicus) on agricultural land. Journal of Applied Ecology, 15, 663-677.

Telle, H. J. (1966). Beitrag zur Kenntnis der Verhaltensweise von Ratten, vergleichend dargestellt bei Rattus norvegicus und Rattus rattus [Contribution to the knowledge of behavioral patterns in two species of rats Rattus norvegicus and Rattus rattus]. Zeitschrift fur Angewandte Zoologie, 53, 129-196.

Valsecchi, P., Choleris, E., Moles, A., Guo, C., \& Mainardi, M. (1996). Kinship and familiarity as factors affecting social transfer of food preferences in adult Mongolian gerbils. Journal of Comparative Psychology, 110, 243-251.

Valsecchi, P., \& Galef, B. G., Jr. (1989). Social influences on the food preferences of house mice (Mus musculus). International Journal of Comparative Psychology, 2, 245-256.

Winocur, G. (1990). Anterograde and retrograde amnesia in rats with dorsal hippocampal or dorsomedial thalamic lesions. Behavioural Brain Research, 38, 145-154.

Received June 7, 2004 Revision received August 23, 2004 Accepted August 30, 2004

\section{Low Publication Prices for APA Members and Affiliates}

Keeping you up-to-date. All APA Fellows, Members, Associates, and Student Affiliates receive-as part of their annual dues-subscriptions to the American Psychologist and APA Monitor. High School Teacher and International Affiliates receive subscriptions to the APA Monitor, and they may subscribe to the American Psychologist at a significantly reduced rate. In addition, all Members and Student Affiliates are eligible for savings of up to $60 \%$ (plus a journal credit) on all other APA journals, as well as significant discounts on subscriptions from cooperating societies and publishers (e.g., the American Association for Counseling and Development, Academic Press, and Human Sciences Press).

Essential resources. APA members and affiliates receive special rates for purchases of APA books, including the Publication Manual of the American Psychological Association, and on dozens of new topical books each year.

Other benefits of membership. Membership in APA also provides eligibility for competitive insurance plans, continuing education programs, reduced APA convention fees, and specialty divisions.

More information. Write to American Psychological Association, Membership Services, 750 First Street, NE, Washington, DC 20002-4242. 